\title{
Coordinate Expression of OPN and Associated Receptors During Monocyte/ Macrophage Differentiation of HL-60 Cells
}

\author{
KEVIN ATKINS, ${ }^{1}$ JANICE E. BERRY, ${ }^{1}$ WEI-ZHEN ZHANG, ${ }^{3}$ JOHN F. HARRIS, ${ }^{2}$ \\ ANN F. CHAMBERS, ${ }^{2}$ ROBERT U. SIMPSON, ${ }^{3}$ AND MARTHA J. SOMERMAN ${ }^{1,3 *}$ \\ ${ }^{1}$ Department of Periodontics/Prevention/Geriatrics, University of Michigan, \\ Ann Arbor, Michigan \\ ${ }^{2}$ Department of Oncology, University of Western Ontario, \\ London, Ontario, Canada \\ ${ }^{3}$ Department of Pharmacology, University of Michigan, Ann Arbor, Michigan
}

\begin{abstract}
Promyelocytic leukemia HL-60 cells promoted by PMA to differentiate along the monocyte pathway adhere to tissue culture plates. To explore the regulation of adhesion molecules in cells promoted to differentiate, the expression and secretion of osteopontin (OPN) and expression of associated cell surface receptors, CD44 and integrin subunits $\alpha_{v}, \beta_{3}, \beta_{1}$, were examined. Results were as follows: 1) PMA induced OPN mRNA and OPN secretion into media; 2$)$ untreated cells expressed $\beta_{1}$ and CD44 mRNA, and PMA induced $\alpha_{v}$ and $\beta_{3}$ mRNA and increased $\beta_{1}$ and CD44 mRNA expression; 3) PMA increased levels of $\alpha_{v}, \beta_{3}, \beta_{1}$ and CD44 protein on the cell surface; and 4) retinoic acid, which promotes granulocytic differentiation of HL-60 cells, did not affect OPN, $\alpha_{v}, \beta_{3}, \beta_{1}$, or CD44 mRNA or protein expression. These data suggest that induction of OPN and associated receptors may play a role during monocytic differentiation of HL-60 cells. J. Cell. Physiol. 175:229-237, 1998. (c) 1998 Wiley-Liss, Inc.
\end{abstract}

Osteopontin (OPN), an adhesion molecule, also known as SPP-1 (secreted phosphoprotein-1), $44 \mathrm{kDa}$, bone sialoprotein I, and the cytokine Eta-1 (early T lymphocyte activation), is a phosphorylated glycoprotein mediating cell attachment and cell migration, at least in vitro, via an arginine-glycine-aspartic acid (RGD) sequence (for review see Butler et al., 1996; Denhardt et al., 1995). OPN has been identified in several tissues, cells, and biological fluids, including bone, kidney, placenta, smooth muscle, neurosensory cells, epithelial cells, blood, milk, urine, activated T lymphocytes, and macrophages. In addition, the process of tumorigenesis and metastasis is correlated with induction of OPN expression (Gardner et al., 1994; Behrend et al., 1994). In spite of extensive research on this molecule, the exact function of OPN remains unknown and most likely is tissue- specific. Broad functions hypothesized for OPN include 1) to facilitate attachment/migration of cells to specific sites (e.g. site of bone development, bone remodeling, inflammation, and tissue repair) (Dodds et al., 1995; Patarca et al., 1993; Reinholt et al., 1990; Ek-Rylander et al., 1994), 2) to modulate crystal formation in mineralized tissues and other biological fluids such as urine (McKee and Nanci, 1995a,b; Hoyer et al., 1995; Hunter et al., 1994; Boskey et al., 1993), and 3) to play a protective role by inhibiting apoptotic events and/or controlling cell function at sites of inflammation (Patarca et al., 1993; Denhardt and Chambers, 1994; Feng et al., 1995).
More specifically, there is substantial evidence that OPN plays a critical role in regulating macrophage activity at sites of wound healing (Miyazaki et al., 1990; Hirota et al., 1993; Giachelli et al., 1995; Singh et al., 1990), which includes the presence of high levels of OPN in macrophages associated with inflammation (Miyazaki et al., 1990; Singh et al., 1990). This has led researchers to hypothesize that OPN has an important function at such sites, including a role in controlling attachment, migration, and phagocytic activity of macrophages in an autocrine fashion, as well as promoting migration of fibroblasts, muscle cells, and endothelial cells to the wound-healing site. However, the precise mechanisms by which OPN affects macrophage behavior have not been elucidated. Furthermore, specific receptors on cell surfaces of macrophages interacting with OPN and subsequently eliciting a variety of cell signaling activities have not been conclusively established. Putative receptors for OPN that may be associated with influencing intracellular signaling pathways

Contract grant sponsor: National Cancer Institute of Canada; Contact grant number: 6015; Contact grant sponsor: NIDR/NIH; Contact grant number: DE10337.

*Correspondence to: Martha J. Somerman, Department of Periodontics/Prevention/Geriatrics, University of Michigan, 1011 N. University Ave., Ann Arbor, MI 48109-1078. E-mail: somerman@umich.edu

Received 7 August 1997; Accepted 24 October 1997 
include $\alpha_{\mathrm{v}} \beta_{3}, \alpha_{\mathrm{v}} \beta_{1}, \alpha_{\mathrm{v}} \beta_{5}$, and CD44 (Giachelli et al., 1995; D’Errico et al., 1995; Teitelbaum et al., 1995; Helfrich et al., 1992; Liaw et al., 1995; Horton et al., 1995; Weber et al., 1996; Somerman et al., 1995). Importantly, RGD containing proteins (Parker et al., 1988; Gresham et al., 1989) and associated receptors (e.g., $\alpha_{v} \beta_{3}$ [Savill et al., 1990; Fadok et al., 1992]) have been implicated as having a role in stimulating phagocytic activity in cells. An understanding of the mechanisms regulating expression of OPN and associated receptors in macrophages is a necessary first step for achieving improved methods for inducing maintenance and repair of tissues.

As an initial approach, we have focused on determining the timed expression of OPN and its putative cell surface receptors during differentiation of HL-60 cells. HL-60 cells, a human promyelocytic leukemic cell line, can be induced to differentiate along both the monocytic/macrophage or granulocyte pathway. Without stimulation, HL-60 cells maintain a rounded morphology and grow in suspension, but, when promoted by phorbol esters to differentiate along the monocyte/macrophage pathway, they become adherent and spread on tissue culture plates (Somerman et al., 1995). In contrast, HL-60 cells induced to differentiate along the granulocyte pathway by retinoic acid do not adhere or spread on tissue culture-treated dishes. The ability of cells differentiating along the monocyte/macrophage pathway to adhere, coupled with several reports suggesting a role for the adhesion molecule osteopontin in the regulation of macrophage and osteoclast activities (for review see Butler et al., 1996; Denhardt et al., 1995; Giachelli et al., 1995), prompted us to determine whether or not HL-60 cells expressed OPN. The results of these initial studies demonstrated that mRNA levels for OPN increased in HL-60 cells exposed to phorbol esters (Somerman et al., 1995). We now extend these studies to more carefully examine the time course of OPN expression and correlation of this expression with that of its putative receptors. These studies are of significance since adhesion molecules and their associated receptors have been implicated as having a role in regulating cell differentiation, yet the precise role of these molecules during cell differentiation warrants further clarification (for review see Hynes, 1992; Lin and Bissell, 1993; Schwartz, 1993; Collins, 1987).

More recently, Andersson and Johansson (1996) demonstrated that the increased expression of OPN mRNA in HL-60 cells is associated with increased adhesion and that the increased adhesion was dependent in part upon the presence of $\alpha_{\mathrm{v}} \beta_{3}$. It was therefore of interest to demonstrate that OPN mRNA expression is mirrored by OPN protein secretion and to investigate whether the expression of receptors associated with OPN is coordinately controlled in phorbol ester-stimulated HL-60 cells.

\section{MATERIALS AND METHODS Reagents}

RPMI 1640 media and fetal calf serum were purchased from GIBCO Life Technologies, Inc. (Rockville, MD). Phorbol 12-myristate 13-acetate (PMA) and retinoic acid were from Sigma (St. Louis, MO). Radiolabeled $\left(\alpha{ }^{32} \mathrm{P}\right) \mathrm{dCTP}(3,000 \mathrm{Ci} / \mathrm{mmol})$ was purchased from
Amersham (Arlington, IL). Trizol total RNA isolation kit was from GIBCO Life Technologies, Inc., and Duralon-UV membranes and random primer kit, Prime-itR-II, were purchased from Stratagene (La Jolla, CA). Monoclonal anti-human integrin $\beta_{1}$ (MAb Ascites, clone P4C10) and anti-human integrin $\alpha_{\mathrm{v}}$ (MAb Ascites, clone VN147) were purchased from GIBCO. Monoclonal anti-human CD61 $\left(\beta_{3}\right.$; MAb Ascites, clone RUU-PL 7F12), mouse $\operatorname{IgG}_{1}$ and IgG $_{2 \mathrm{a}}$ monoclonal control, and FITC-labeled goat anti-mouse IgG were purchased from Becton Dickinson (San Jose, CA). Monoclonal anti-human CD44 (purified, clone A3D3), which recognizes all CD44 isoforms, was purchased from Sigma.

\section{cDNA probes}

The cDNA probes used for these studies included a human OPN cDNA, a gift from Dr. Marion Young (Young et al., 1990) (NIDR/NIH), human $\alpha_{v}, \beta_{1}$, and $\beta_{3}$ placenta cDNA, kindly provided by Dr. Scott Argraves (Argraves et al., 1987), CD44 (American Type Culture Collection (ATCC), Rockville, MD), a cDNA for chicken glyceraldehyde-3-phosphate dehydrogenase (GAPDH) (Dugaiczyk et al., 1983), and a cDNA for 18S rRNA (Kenneth Zaret, Brown University, Providence, RI).

\section{Cell culture}

HL-60 cells, obtained from American Type Culture Collection, were cultured in RPMI 1640 media supplemented with $10 \%$ fetal calf serum, $2 \mathrm{mM}$ L-glutamine, $100 \mathrm{IU} / \mathrm{ml}$ penicillin, and $100 \mathrm{mg} / \mathrm{ml}$ streptomycin. Cells were used between passage 20 and 45 . For experiments, cells were seeded at a $2 \times 10^{5}$ cells $/ \mathrm{ml}$ and treated with vehicle control (ethanol), PMA at doses of $0.15 \mathrm{nM}, 0.5 \mathrm{nM}$, or $1.5 \mathrm{nM}$, or retinoic acid (RA) at doses of $10 \mathrm{nM}, 100 \mathrm{nM}$, or $1000 \mathrm{nM}$. All experiments were replicated at least three times. Dose selection was based on previous studies in our laboratory demonstrating induction of differentiation by PMA along the monocyte pathway or by RA along the granulocyte pathway, as measured by function assays (nonspecific esterase (NSE) activity and nitroblue tetrazolium (NBT) dye reduction assay), cell attachment (PMA only), and changes in cell morphology (for review see Tsiftsoglou and Robinson, 1992). Assays, including NBT, NSE, and morphological changes, were run routinely to assure that cells were functionally similar.

\section{Northern blot analysis}

Cells were harvested at specified times from $6 \mathrm{~h}$ to $72 \mathrm{~h}$ and total RNA isolated using Trizol reagent. Equal amounts of RNA (20 $\mu \mathrm{g} /$ lane $)$ were denatured and electrophoresed on $1.2 \%$ agarose- $6 \%$ formaldehyde gels, transferred to a Duralon-UV membrane, and immobilized by UV cross-linking (Stratalinker; Stratagene). Membranes were hybridized with the indicated $\alpha{ }^{32} \mathrm{P}$ cDNA probes labeled using a Prime-itR-II random primer kit, washed under standard conditions, and exposed to X-ray film (Kodak X-Omat AR, Rochester, NY) with intensifying screens at $-70^{\circ} \mathrm{C}$. GAPDH and $18 \mathrm{~S}$ marker were used to account for any differences in loading concentrations. All experiments were repeated at least three times. 


\section{ELISA}

A "capture" ELISA method, developed by Bautista et al. (1996), was used to measure levels of OPN in media from HL-60 cells exposed to PMA. For this assay, a combination of a high affinity mouse monoclonal antibody, mAb53 (Bautista et al., 1994), for the capture step, and a rabbit polyclonal antiserum, for amplification, both raised against a recombinant glutathione-Stransferase-human OPN fusion protein (GST-hOPN), were used (Xuan et al., 1994).

Briefly, immunoassay plates (Life Technologies, Burlington, Ontario, Canada) were prepared by coating with antibody mAb53 $(100 \mu \mathrm{l} / \mathrm{well}, 10 \mu \mathrm{g} / \mathrm{ml}$ in $0.1 \mathrm{M}$ sodium bicarbonate, $\mathrm{pH} 9.0,4 \mathrm{C}, 16 \mathrm{~h}$ ) and then blocking with $1 \%$ BSA in ST-Tween buffer [10 mM Tris, $\mathrm{pH} 8.0$, $150 \mathrm{mM} \mathrm{NaCl}$, and $0.05 \%$ Tween-20 (Bio-Rad, Mississauga, Ontario)]. Prepared plates were then washed extensively with ST-Tween buffer. Samples of tissue culture media, obtained from cells treated as described above, were diluted into wells containing ST-Tween buffer with $1 \% \mathrm{BSA}$ as diluent and incubated at $37^{\circ} \mathrm{C}$ for $1.5 \mathrm{~h}$. Triplicates of at least threefold dilutions of each sample (starting at 1/3) were tested. Subsequent incubations were performed at $37^{\circ} \mathrm{C}$ for $\frac{1}{2} \mathrm{~h}$ each, except as indicated, followed by three washes in ST-Tween buffer. In order to amplify and detect captured OPN, we sequentially incubated wells with 1) rabbit antiOPN antiserum $(1 / 1,000), 2)$ biotinylated goat anti-rabbit Ig antibody $(1 / 2,000)$ (Life Technologies), and 3) streptavidin conjugated with alkaline phosphatase (1/ 2,000) (Jackson Immunological Laboratories, Inc., West Grove, PA). For color development, wells were incubated with $100 \mu \mathrm{l}$ of p-nitrophenyl phosphate (1 $\mathrm{mg} / \mathrm{ml}$ in $100 \mathrm{mM}$ Tris, $\mathrm{pH} 9.5,100 \mathrm{mM} \mathrm{NaCl}$, and 5 $\mathrm{mM} \mathrm{MgCl}_{2}$ ), and the signal was allowed to develop at room temperature for 4-6 min. To stop the reaction, $50 \mu \mathrm{l}$ of $0.2 \mathrm{M} \mathrm{Na}_{2}$ EDTA ( $\mathrm{pH}$ 8.0) was added. A BioRad plate reader was used to quantify the signal. Recombinant GST-OPN fusion protein was used as a standard (Bautista et al., 1994, 1996). For quantification of OPN, the curve-fitting feature of SigmaPlot (Jandel Scientific, San Jose, CA) was used to fit data points for the protein standard into the exponential rise function. The best-fit curve was used to extrapolate unknown values when the signal was in the linear region of the standard curve. Results were expressed as mean \pm SD. Data were analyzed using Student $t$-test for unpaired samples. Values of $P<0.05$ were considered statistically significant.

\section{Flow cytometry}

After 24 and $72 \mathrm{~h}$ of treatment, cells were harvested using Puck's EDTA and washed twice with phosphatebuffered saline (PBS). Cell viability was determined by flow cytometry using ethidium monoazide. Washed cells were resuspended in PBS at $1 \times 10^{7} \mathrm{cell} / \mathrm{ml}$, and $100 \mu \mathrm{l}$ of each sample was incubated with saturating concentrations of the indicated MAb (concentrations determined by titration) or matched mouse Ig as negative control for 30 min at room temperature. Samples were then washed and incubated with fluoresceinated goat anti-mouse secondary antibody for $30 \mathrm{~min}$, washed again, and fixed with $1 \%$ formaldehyde in PBS $(\mathrm{pH}$

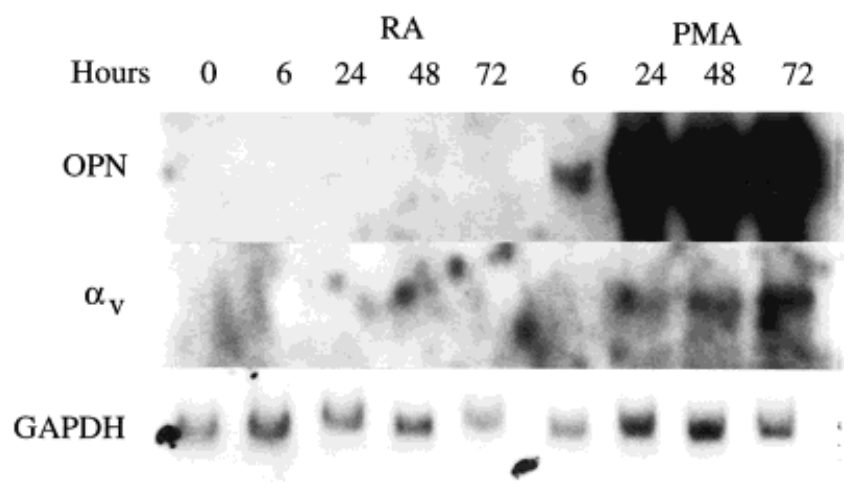

Fig. 1. Time course for expression of $\alpha_{\mathrm{v}}$ and OPN mRNA in HL-60 cells treated with $1.5 \mathrm{nM}$ PMA or $100 \mathrm{nM}$ RA. HL-60 cells were grown for the indicated times in the presence of agents or vehicle control, $0.1 \%$ ethanol, before isolation of RNA. Northern blots containing 20 $\mu \mathrm{g}$ RNA/lane were hybridized to $\alpha_{\mathrm{v}}$ and OPN cDNAs as described in Materials and Methods. GAPDH mRNA was used to normalize the loading of mRNA.

7.4). Labeled cells were analyzed on an Epics C Flow Cytometer (Coulter Electronics, Hialeah, FL) with 200 $\mathrm{mW}$ of laser power tuned to $488 \mathrm{~nm}$. Log forward light scatter and $\log 90^{\circ}$ light scatter were used to gate out debris, and fluorescence was measured at $525+/-25$ $\mathrm{nm}$ for fluorescein. Five thousand gated events were collected for each sample and plotted on a 3 decade fluorescence scale. Files were converted to Macintosh format and plotted using CricketGraph and MacDraw. Mean channel fluorescence was calculated using Coulter's StatPak statistical analysis program and then converted to specific linear fluorescence (Muirhead, et al., 1983; Todd, et al., 1988).

\section{RESULTS \\ Effect of PMA and retinoic acid treatment on mRNA expression for OPN and $\alpha_{v}$ in HL-60 cells}

Data provided in Figure 1 demonstrate that untreated HL-60 cells do not express OPN or $\alpha_{\mathrm{v}}$ mRNA. Cells exposed to PMA for $6 \mathrm{~h}$ expressed OPN but not $\alpha_{\mathrm{v}}$ mRNA. Increased expression for OPN was observed at $24 \mathrm{~h}$ and maintained throughout the time period of this experiment (i.e., $72 \mathrm{~h}$ ). These PMA-treated cells exhibited a similar time course for adhesion, with changes in morphology from rounded to more spread, apparent at $6 \mathrm{~h}$, followed by approximately $75 \%$ of the cells adhering to dishes by $24 \mathrm{~h}$ and $90 \%$ adhesion at $48 \mathrm{~h}$ (data not shown). $\alpha_{\mathrm{v}}$ mRNA expression was apparent at $24 \mathrm{~h}$ of PMA treatment and increased thereafter to $72 \mathrm{~h}$. In contrast, cells exposed to retinoic acid did not express OPN and $\alpha_{\mathrm{v}}$ mRNA, nor did they exhibit adhesive properties at any of the time points examined, from $6-72 \mathrm{~h}$.

\section{Effect of PMA and retinoic acid treatment on $\beta_{1}$ and $\beta_{\mathbf{3}}$ mRNA in HL-60 cells}

RNA levels for two integrin subunits associated with OPN, $\beta_{1}$ and $\beta_{3}$, were determined in untreated HL-60 cells and in HL-60 cells treated with PMA or RA. As seen in Figure 2, untreated cells express mRNA for $\beta_{1}$ but not for $\beta_{3}$. Thus, $\beta_{1}$ is constitutively expressed, at 
A

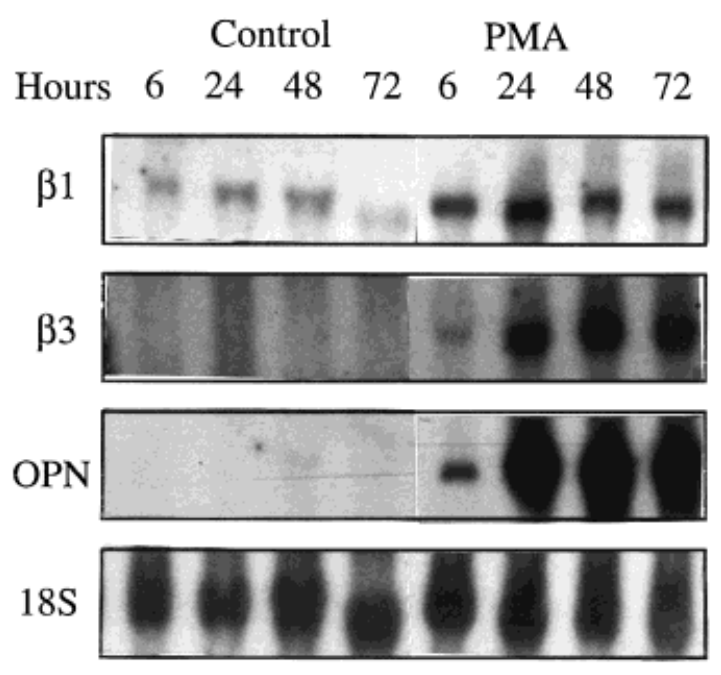

Fig. 2. Time course for expression of $\beta_{1}$ and $\beta_{3}$ mRNA in HL-60 cells treated with $1.5 \mathrm{nM}$ PMA (A) or $100 \mathrm{nM}$ RA (B). HL-60 cells were grown for the indicated times in the presence of agents or vehicle control, $0.1 \%$ ethanol, before isolation of RNA. Northern blots con-

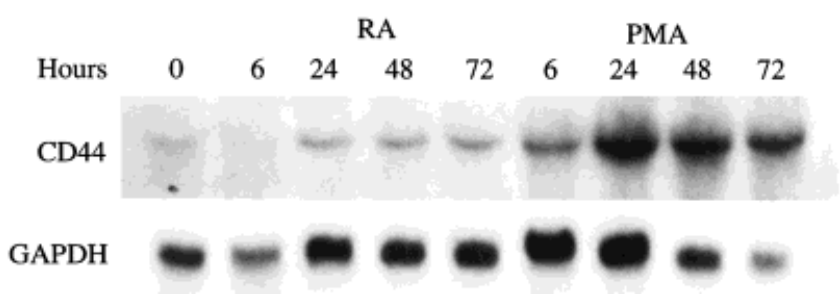

Fig. 3. Time course for expression of CD44 mRNA in HL-60 cells treated with $1.5 \mathrm{nM}$ PMA or $100 \mathrm{nM}$ RA. HL-60 cells were grown for the indicated times in the presence of agents or vehicle control, $0.1 \%$ ethanol, before isolation of RNA. Northern blots containing $20 \mu \mathrm{g}$ RNA/lane were hybridized to CD44 cDNA as described in Materials and Methods. GAPDH mRNA was used to normalize the loading of mRNA.

low levels, in HL-60 cells, as reported previously (Bohnsack et al., 1995). However, exposure of HL-60 cells to PMA resulted in an enhancement of $\beta_{1}$ mRNA which was observed as early as $6 \mathrm{~h}$ and maintained up to 72 h. In contrast, exposure to RA did not result in $\beta_{1}$ mRNA levels beyond that seen in unstimulated HL-60 cells. HL-60 cells exposed to PMA expressed $\beta_{3}$ mRNA, with expression noted at $6 \mathrm{~h}$, peaking at $24 \mathrm{~h}$, and maintained up to $72 \mathrm{~h}$. RA did not promote $\beta_{3}$ mRNA expression in HL-60 cells.

\section{Effect of PMA and retinoic acid treatment on CD44 mRNA in HL-60 cells}

Basal expression of CD44 mRNA, a cell surface receptor for OPN (Weber et al., 1996), was noted in untreated HL-60 cells (Fig. 3). PMA treatment increased
B

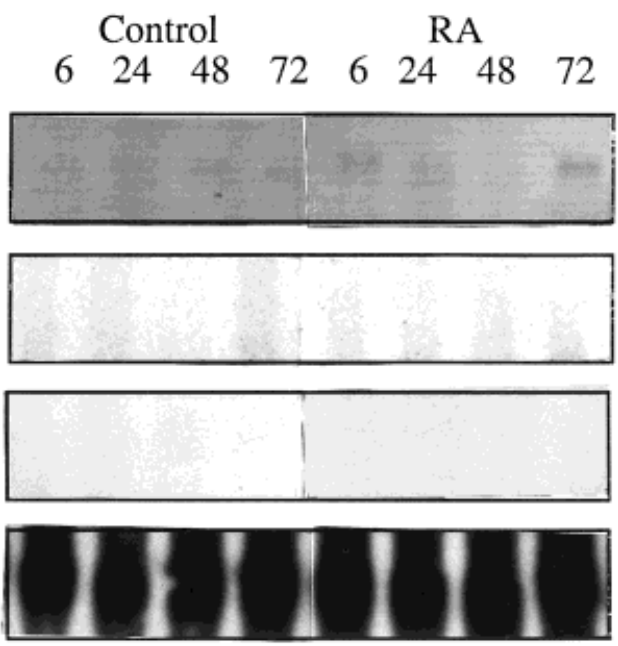

taining $20 \mu \mathrm{g}$ RNA/lane were hybridized to $\beta_{1}$ and $\beta_{3}$ cDNAs as described in Materials and Methods. The loading of mRNA was normalized with 18s RNA.

the expression of message for CD44 by $24 \mathrm{~h}$ with a further increase up to $72 \mathrm{~h}$. RA treatment of HL-60 cells was without effect on CD44 mRNA expression.

\section{PMA increased the secretion of OPN protein by HL-60 cells in a time-dependent manner}

To determine whether cells expressing OPN mRNA were secreting this protein, we determined the concentration of OPN in media from HL-60 cells exposed to PMA at designated time points using an ELISA method (Bautist, et al., 1996). As shown in Figure 4, PMA (0.5 $\mathrm{nM}$ ) induced secretion of OPN by HL-60 cells. Measurable levels of OPN in media were noted by $24 \mathrm{~h}$ and increased steadily up to $72 \mathrm{~h}$, with no further increase seen at $96 \mathrm{~h}$. Similar results were observed in cells exposed to $1.5 \mathrm{nM}$ PMA. There was no OPN secretion in media from untreated cells or from cells treated with RA.

Effect of PMA and retinoic acid treatment on cell surface expression of $\beta_{1}, \beta_{3}, \alpha_{v}$ in HL-60 cells

Having established the mRNA expression pattern for OPN-associated receptors, we conducted studies to determine whether the appearance on the cell surface by these receptors correlated with their respective message. The effect of PMA and RA treatment of HL-60 cells on expression of cell surface integrins was determined by flow cytometry (Fig. 5). Untreated HL-60 cells constitutively express $\beta_{1}$ on their cell surface, with increased expression noted at $6 \mathrm{~h}$ and increasing up to $72 \mathrm{~h}$ in cells exposed to PMA. RA had no effect on $\beta_{1}$ cell surface expression beyond that seen with untreated cells (Fig. 5C). Untreated HL-60 cells did not express either $\alpha_{\mathrm{v}}$ or $\beta_{3}$, but treatment with PMA caused an 


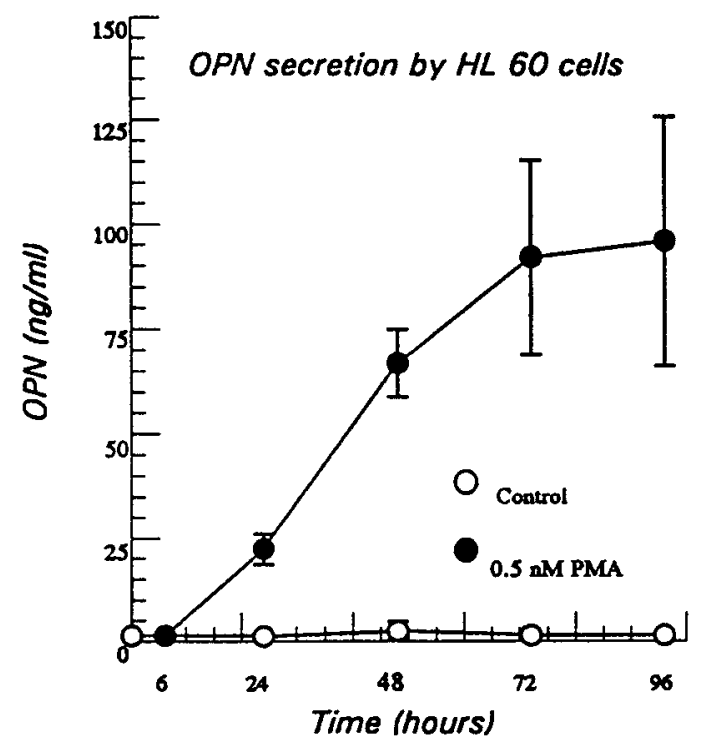

Fig. 4. OPN secretion in HL-60 cells treated with PMA, as measured by ELISA. The concentration of OPN in medium was measured at specific time points $(24,42,72,96 \mathrm{~h})$ after exposure of cells to PMA (0.5 nM). Results are expressed as $\mathrm{ng} / \mathrm{ml}$ of OPN, using recombinant GST-OPN fusion protein as a standard (Argraves et al., 1987; Dugaiczyk et al., 1983). This is a representative experiment; this result was reproducible in two separate experiments. Error bars represent mean $\pm \mathrm{SD}$ of triplicate samples at each time point.

increase in both integrins on the cell surface by $24 \mathrm{~h}$, with a substantial effect noted by $72 \mathrm{~h}$. In contrast, cells treated with RA for up to $72 \mathrm{~h}$ did not express $\alpha_{\mathrm{v}}$ or $\beta_{3}$ on their cell surface (Fig. $5 \mathrm{~A}$ and $5 \mathrm{~B}$ ).

\section{Effect of PMA and retinoic acid treatment on cell surface expression of CD44 in HL-60 cells}

Untreated HL-60 cells constitutively express CD44 (Fig. 5D). This level of expression was increased with addition of PMA by $24 \mathrm{~h}$, and this increase was sustained at $72 \mathrm{~h}$. Conversely, CD44 levels were unchanged in cells exposed to RA.

\section{DISCUSSION}

Previous work (Somerman et al., 1995), confirmed here, demonstrated that OPN and $\alpha_{\mathrm{v}}$ mRNA expression is stimulated by PMA. Furthermore, the increased adhesion of HL- 60 cells stimulated by PMA has been demonstrated to be associated with OPN mRNA expression and mediated, at least in part, by $\alpha_{v} \beta_{3}$ (Andersson and Johansson, 1996). It is possible, therefore, that changes in cell surface receptor expression are important factors controlling HL-60 differentiation. This investigation focused on determining whether OPN-associated cell surface receptors, CD44 and the integrin subunits, $\alpha_{\mathrm{v}}, \beta_{3}$, and $\beta_{1}$, are regulated concurrently with OPN during differentiation of HL-60 cells along the monocyte/macrophage pathway. The findings indicate that PMA-induced differentiation of HL-60 cells along the monocyte/ macrophage pathway results in increased expression and secretion of OPN and also in increased expression of CD44 and the integrins $\alpha_{\mathrm{v}}, \beta_{3}$, and $\beta_{1}$. In contrast, retinoic acid does not stimulate OPN or receptor expression in HL-60 cells.

Phorbol ester induction of OPN mRNA expression in HL-60 cells occurs prior to other PMA-induced changes in cells associated with differentiation (e.g., adhesion and induction of NSE activity) (Somerman, et al., 1995). It was interesting to note that changes in CD44 and integrin mRNA levels and cell surface receptor expression are later events correlating with the time of expression of other markers associated with differentiation of HL-60 cells along the monocyte/macrophage pathway. It is possible that increased secretion of OPN by HL-60 cells regulates expression of OPN associated receptors. Substantial evidence exists demonstrating that the extracellular matrix to which cells are exposed can control the expression of both mRNA and protein levels of a variety of integrins (for review see Lin and Bissell, 1993). OPN, through both alterations in receptor expression and internal signaling activities, may play a critical role in regulating recruitment of specific cell types (e.g. macrophages and osteoclasts) to a healing site. In support of this, high levels of OPN have been demonstrated in osteoclasts and in macrophages associated with inflammation, wound repair, bone remodeling, and pathological diseases (Miyazaki et al., 1990; Hirota et al., 1993; Giachelli et al., 1995; Murray et al., 1994). In addition, OPN exhibits chemotactic activity for several cell types including early T lymphocytes (Singh, et al., 1990) and fibroblasts (Weber et al., 1996).

The question arises as to the role that each of the cell surface receptors plays with regard to OPN function. OPN promotes attachment of macrophages and osteoclasts in vitro (Singh et al., 1990), and evidence has been provided to indicate that $\alpha_{v} \beta_{3}$, identified on both macrophages and osteoclasts, is involved in promoting phagocytic activity (Savill et al., 1990; Fadok et al., 1992). The $\alpha_{v} \beta_{3}$ integrin has also been reported to participate in OPN-mediated HL-60 cellular adhesion stimulated by PMA (Andersson and Johansson, 1996). In addition to $\alpha_{v} \beta_{3}$, other integrins, such as $\alpha_{v} \beta_{1}$, have been identified on monocytes/macrophages and osteoclasts and thus may also be involved in OPN-mediated cell signaling. The CD44 receptor, which is involved in homing, attachment, and aggregation of hematopoitic cells, binds OPN (Weber et al., 1996). This binding apparently mediates both adhesion and chemotaxis (Weber et al., 1996). The coordinated expression of OPN and each of the surface receptors may reflect the different requirements for homing, migration (extravasation) and finally attachment. For example, it is possible that CD44 mediates cell homing and migration, while $\alpha_{\mathrm{v}} \beta_{3}$ functions via final cell attachment. In summary, results shown here demonstrate that expression of OPN and its associated receptors are induced and/or enhanced during differentiation of HL-60 cells along the monocyte/macrophage pathway.

Future studies, directed at blocking the expression of these molecules during differentiation of cells along the monocyte/macrophage pathway, will help to clarify the significance of these molecules in the differentiation 


\section{A. $\beta_{3}$ Integrin}
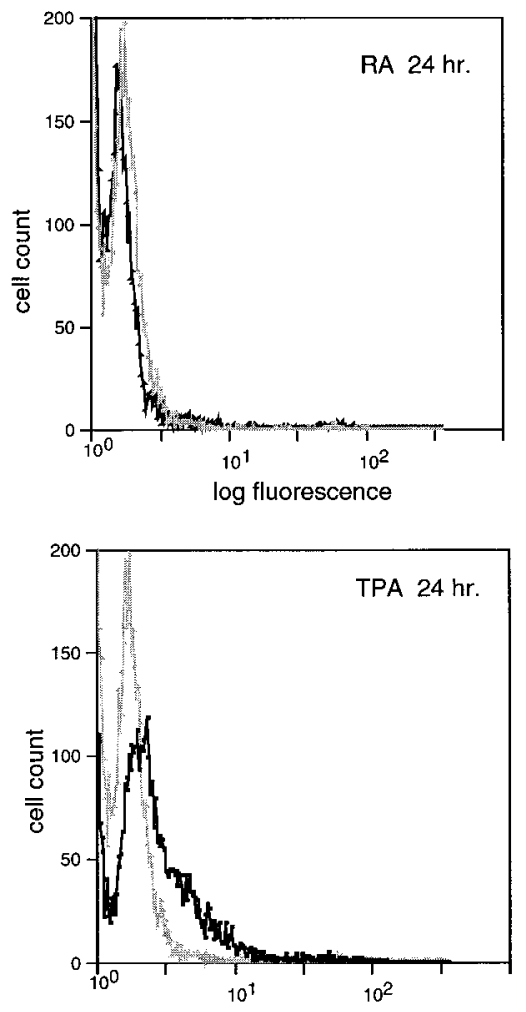

$\log$ fluorescence
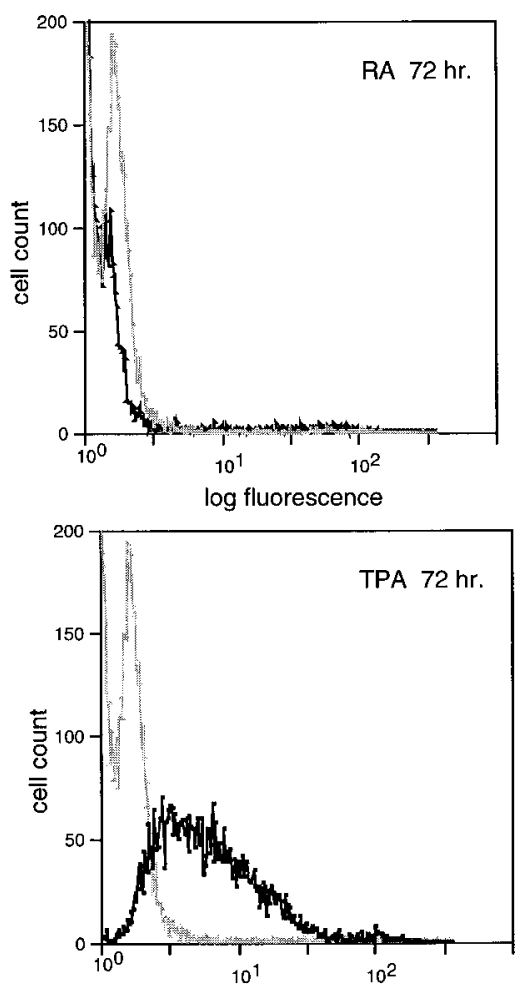

$\log$ fluorescence
B. $\alpha_{v}$ Integrin
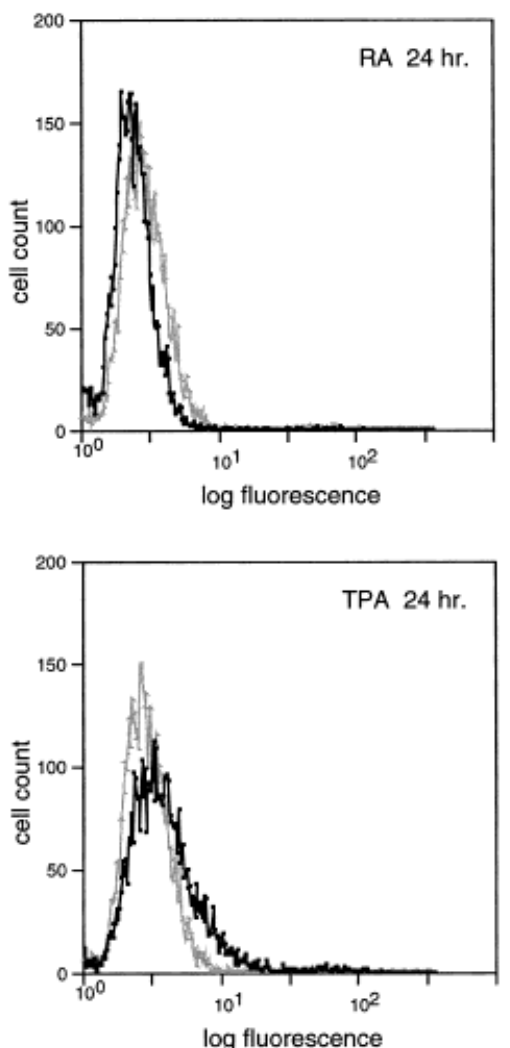
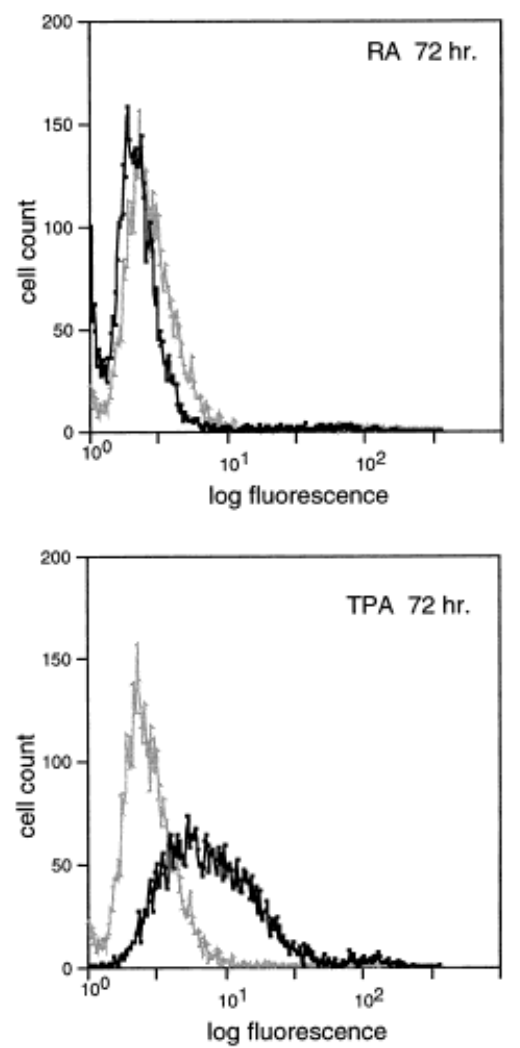

Fig. 5 Expression of $\alpha_{v}, \beta_{1}$, and $\beta_{3}$ integrins and CD44 on the cell surface of HL60 cells as measured by flow cytometry. HL60 cells were cultured in the presence (or absence/control) of $1.5 \mathrm{nM}$ PMA or $100 \mathrm{nM}$ RA for $24 \mathrm{~h}$ or $72 \mathrm{~h}$. Cells were stained with either Ig matched mouse immunoglobulin (light peak) or primary antibodies (dark peak) against the integrin subunits, human $\beta_{3}(\mathbf{A}), \alpha_{\mathrm{v}}(\mathbf{B}), \beta_{1}(\mathbf{C})$, or CD44 (D). FITC-labeled secondary antibody was applied, and cells were analyzed by flow cytometry. The $\mathrm{y}$ axis represents cell number, and the $\mathrm{x}$ axis represents log fluorescence intensity. Results were from one representative experiment; the pattern shown here was reproduced in four separate experiments. 
C. $\beta_{1}$ Integrin
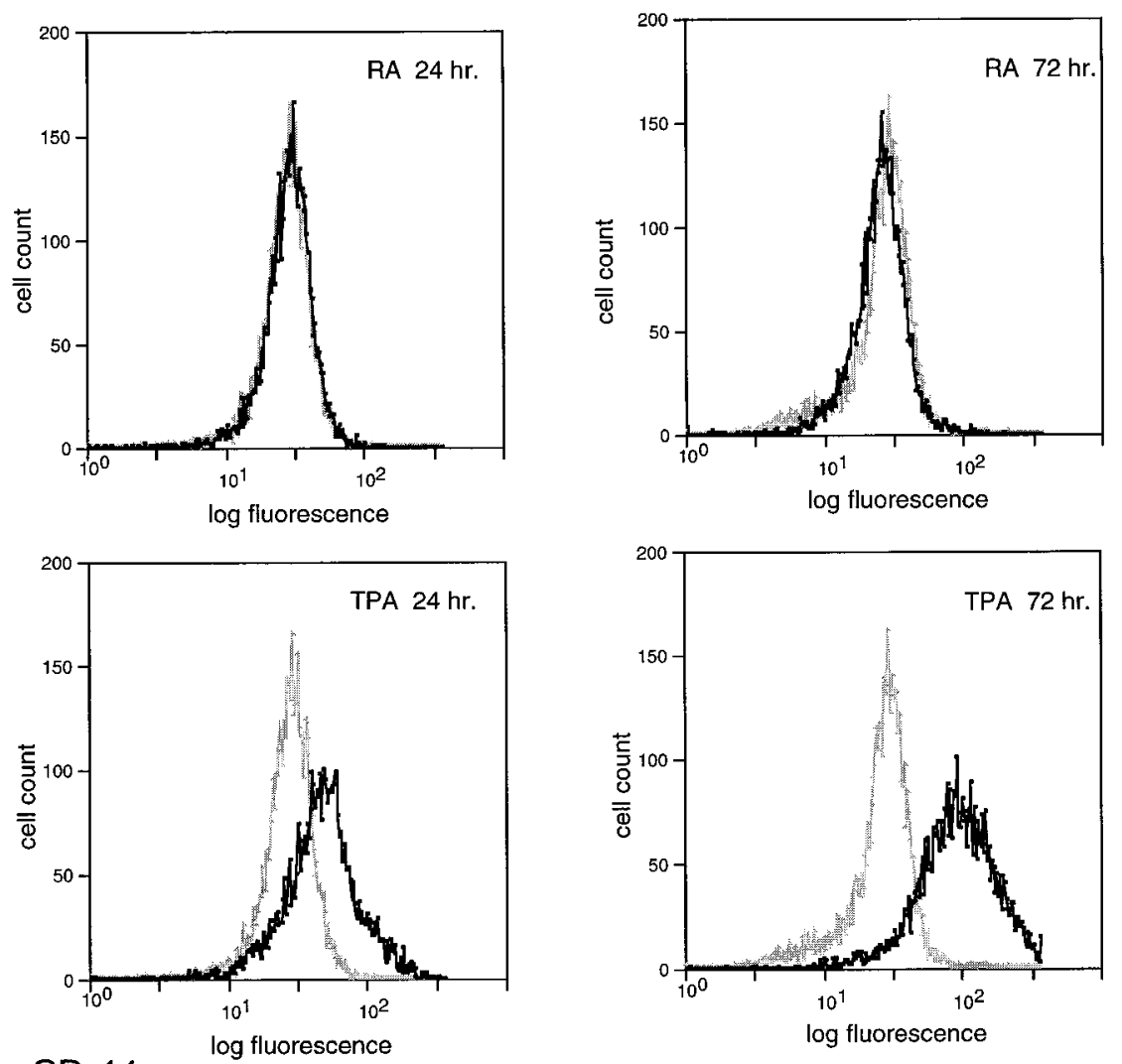

D. $\mathrm{CD}-44$
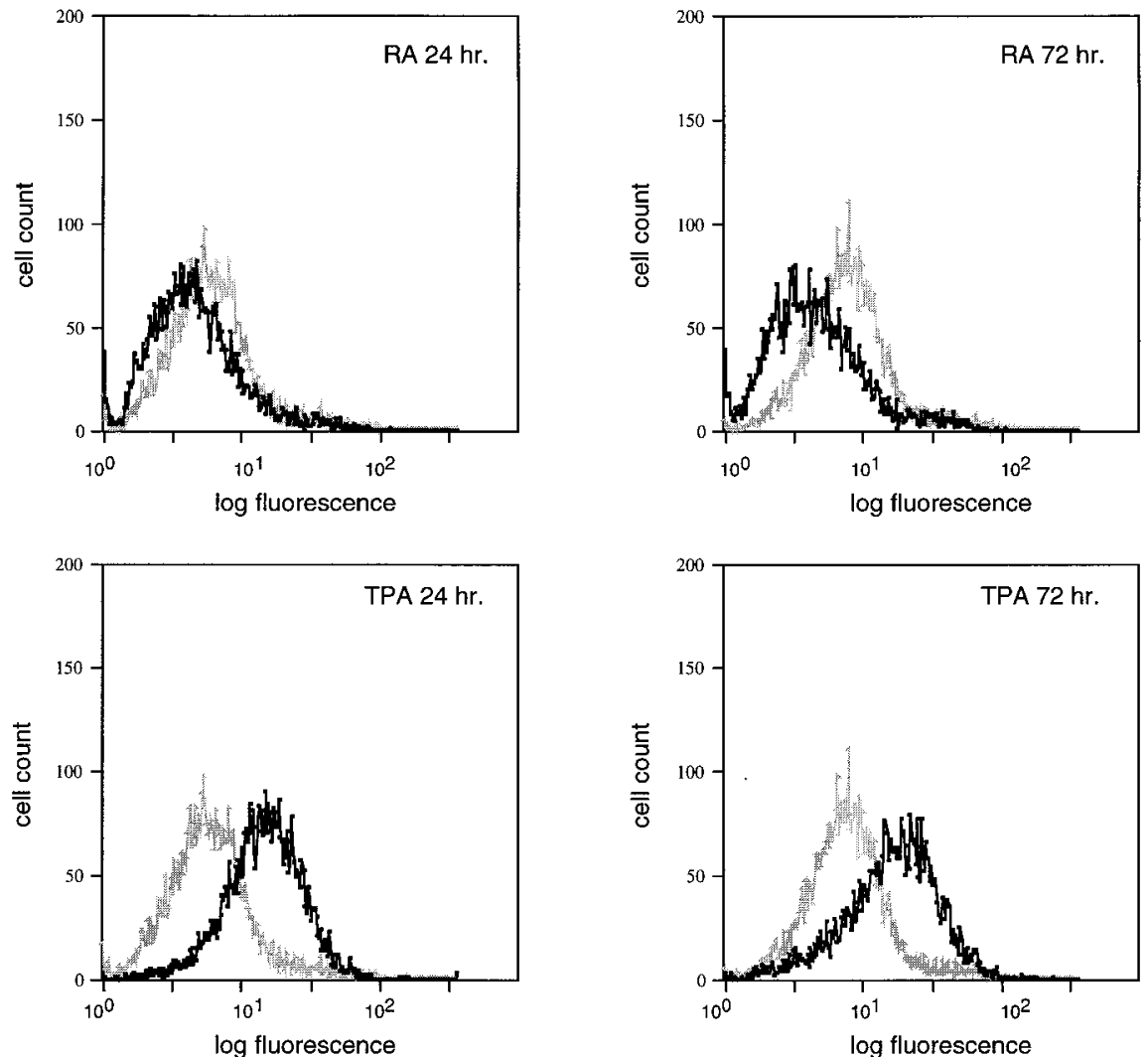

Fig. 5. (Continued.) 
process. Delineation of the role that each of these receptors plays in relation to OPN during differentiation will be useful in defining the function of OPN in that process.

\section{ACKNOWLEDGMENTS}

This study was supported by National Cancer Institute of Canada grant 6015 to A.F.C. and NIDR/NIH grant DE10337.

\section{LITERATURE CITED}

Andersson, G., and Johansson, E.-K. (1996) Adhesion of human myelomonocytic (HL-60) cells induced by 1,25-dihydroxyvitamin D3 and phorbol myristate acetate is dependent on osteopontin synthesis and the $\alpha_{v} \beta_{3}$ integrin. Connect. Tissue Res., 35:163171 [217-225].

Argraves, W. S., Suzuki, S., Arai, H., Thompson, K., Pierschbacher, M.D., and Ruoslahti, E. (1987) Amino acid sequence of the human fibronectin receptor. J. Cell. Biol., 105:1183-1190.

Bautista, D.S., Denstedt, J., Chambers, A.F., and Harris, J.F. (1996) Low molecular weight variants of osteopontin generated by serine proteinases in urine of patients with kidney stones. J. Cell Biochem, 61:402-409.

Bautista, D.S., Xuan, J.-W., Hota, C., Chambers, A.F., and Harris, J.F. (1994) Inhibition of arg-gly-asp (RGD)-mediated cell adhesion to osteopontin by a monoclonal antibody against osteopontin. J. Biol. Chem., 269:23280-23285.

Behrend, E.I., Craig, A.M., Wilson, S.M., Denhardt, D.T., and Chambers, A.F. (1994) Reduced malignancy of ras-transformed NIH 3T3 cells expressing antisense osteopontin RNA. Cancer Res., 54:832837.

Bohnsack, J.F., Chang, J., Zhou, X., and Yednock, T.A. (1995) Mechanisms of $\beta_{1}$ integrin-dependent adherence of granulocytic HL-60 to fibronectin. J. Leukoc. Biol., 57:592-599.

Boskey, A.L., Maresca, M., Ullrich, W., Doty, S.B., Butler, W.T., and Prince, C.W. (1993) Osteopontin-hydroxyapatite interaction in vitro: Inhibition of hydroxyapatite formation and growth in a gelatin-gel. Bone Miner., 22:147-159.

Butler, W.T., Ridall, A.L., and McKee, M.D. (1996) Osteopontin. In: Principles of Bone Biology. J.P. Bilizikian, L.G. Raisz, and G.A. Rodan, eds. Academic Press, New York, pp. 167-182.

Collins, S. (1987) The HL-60 promyelocytic leukemia cell line: Proliferation, differentiation, and cellular oncogene expression. Blood, $70: 1233-1244$.

D’Errico, J.A., Sauk, J.J., Prince, C.W., and Somerman, M.J. (1995) Osteopontin adhesion receptor on gingival fibroblasts. J. Periodont. Res., 30:34-41.

Denhardt, D.T., and Chambers, A.F. (1994) Overcoming obstacles to metastasis/defenses against host defenses: Osteopontin as a shield against attack by cytotoxic host cells. J. Cell. Biochem., 56:48-51.

Denhardt, D.T., Butler, W.T., Chambers, A.F., and Senger, D.R., eds (1995) Osteopontin: Role in cell signaling and adhesion. Ann. N. Y. Acad. Sci., 760:1-388.

Dodds, R.A., Connor, J.R., James, I.E., Rykaczewski, E.L., Appelbaum, E., Dul, E., and Gowen, M. (1995) Human osteoclasts, not osteoblasts, deposit osteopontin onto resorption surfaces: An in vitro and ex vivo study of remodeling bone. J. Bone Miner. Res., 10:16661680.

Dugaiczyk, A., Haron, J.A., Stone, E.M., Dennison, O.E., Rothblum, K.N., and Scwartz, R.J. (1983) Cloning and sequencing of a deoxyribonucleic acid copy of glyceraldehyde-3-phosphate dehydrogenase messenger ribonucleic acid isoloated from chicken muscle. Biochemistry, 22:1605-1613.

Ek-Rylander, B., Flores, M., Wendel, M., Heinegard, D., and Andersson, G. (1994) Dephosphorylation of osteopontin and bone sialoprotein by osteoclastic tartrate-resistant acid phosphatase. Modulation of osteoclast adhesion in vitro. J. Biol. Chem., 269:14853-14856.

Fadok, V.A., Savill, J.S., Haslett, C., Bratton, D.L., Doherty, D.E., Campbell, P.A., and Henson, P.M. (1992) Different populations of macrophages use either the vitronectin receptor or the phosphatidylserine receptor to recognize and remove apoptotic cells. J. Immunol., 149:4029-4035.

Feng, B., Rollo, E.E., and Denhardt, D.T. (1995) Osteopontin (OPN) may facilitate metastasis by protecting cells from macrophage NO mediated cytotoxicity: Evidence from cells lines down-regulated for
OPN expression by a targeted ribozyme. Clin. Exp. Metastasis, 13:453-462.

Gardner, H.A.R., Berse, B., and Senger, D.R. (1994) Specific reduction in osteopontin synthesis by antisense RNA inhibits the tumorigenicity of transformed Rat1 fibroblasts. Oncogene, 9:2321-2326.

Giachelli, C.M., Schwartz, S.M., and Liaw, L. (1995) Molecular and cellular biology of osteopontin. Potential role in cardiovascular disease. Trends Cardiovasc. Med., 5:88-95.

Gresham, H.D., Goodwin, J.L., Allen, P.M., Anderson, D.C., and Brown, E.J. (1989) A novel member of the integrin receptor family mediates arg-gly-asp-stimulated neutrophil phagocytosis. J. Cell. Biol., 108:1935-1943.

Helfrich, M.H., Nesbitt, S.A., Dorey, E.L., and Horton, M.A. (1992) Rat osteoclasts adhere to a wide range of RGD (arg-gly-asp) peptidecontaining proteins, including the bone sialoproteins and fibronectin, via beta 3 integrin. J. Bone Miner. Res., 7:335-343.

Hirota, S., Imakita, M., Kohri, K., Ito, A., Morii, E., Adachi, S., Kim, H.M., Kitamura, Y., Yutani, C., and Nomura, S. (1993) Expression of osteopontin messenger RNA by macrophages in atherosclerotic plaques. A possible association with calcification. Am. J. Pathol., 143:1003-1008.

Horton, M.A., Nesbit, M.A., and Helfrich, M.A. (1995) Interaction of osteopontin with osteoclast integrins. Ann. N. Y. Acad. Sci., 760:190-200.

Hoyer, J.R., Otvos, L., Jr., and Urge, L. (1995) Osteopontin in urinary stone formation. Ann. N. Y. Acad. Sci., 760:257-265.

Hunter, G.K., Kyle, C.L., and Goldberg, H.A. (1994) Modulation of crystal formation by bone phosphoproteins: Structural specificity of the osteopontin mediated inhibition of hydroxyapatite formation. Biochem. J., 300:723-728.

Hynes, R.O. (1992) Integrins: Versatility, modulation and signaling in cell adhesion. Cell, 69:11-25.

Liaw, L., Skinner, M.P., Raines, E.W., Ross, R., Cheresh, D.A., Schwartz, S.M., and Giachelli, C.M. (1995) The adhesive and migratory effects of osteopontin are mediated via distinct cell surface integrins. J. Clin. Invest., 95:713-724.

Lin, C.Q., and Bissell, M. (1993) Multi-faceted regulation of cell differentiation by extracellular matrix. FASEB J., 7:734-743.

McKee, M.D., and Nanci, A. (1995a) Osteopontin and the bone remodeling sequence. Ann. N. Y. Acad. Sci., 760:177-189.

McKee, M.D., and Nanci, A. (1995b) Post-embedding colloidal-gold immunocytochemistry of noncollagenous extracellular matrix proteins in mineralized tissues. Microsc. Res. Tech., 31:44-62.

Miyazaki, Y., Setoguchi, M., Yoshida, S., Higuchi, Y., Akizuki, S., and Yamamoto, S. (1990) The mouse osteopontin gene: Expression in monocytic lineages and complete nucleotide sequence. J. Biol. Chem., 265:14432-14438.

Muirhead, K.A. Schmidt, T.C., and Muirhead, A.R. (1983) Determination of linear fluorescence intensities from flow cytometric data accummulated with logarithmic amplification. Cytometry, $3: 251-256$

Murray, C.E., Giachelli, C.M., Schwartz, S.M., and Vracko, R. (1994) Macrophages express osteopontin during repair of myocardial necrosis. Am. J. Pathol., 145:1450-1462.

Parker, C.J., Frame, R.N., and Elstad, M.R. (1988) Vitronectin (S protein) augments the functional activity of monocyte receptors for IgG and complement C3b. Blood, 71:86-93.

Patarca, R., Saavedra, R.A., and Cantor, H. (1993) Molecular and cellular basis of genetic resistance to bacterial infection: The role of the early T-lymphocyte activation-1/osteopontin gene. Crit. Rev. Immunol., 13:225-246.

Reinholt, F.P., Hultenby, K., Oldberg, A., and Heinegard, D. (1990) Osteopontin: A possible anchor of osteoclasts to bone. Proc. Natl. Acad. Sci. U. S. A., 87:4473-4475.

Savill, J., Dransfield, I., Hogg, N., and Haslett, C. (1990) Vitronectin receptor-mediated phagocytosis of cells undergoing apoptosis. Nature, 343:170-173.

Schwartz, M.A. (1993) Signaling by integrins: Implication for tumorigenesis. Cancer Res., 51:1503-1505.

Singh, R.P., Patarca, R., Schwart, J., Singh, P., and Cantor, H. (1990) Definition of a specific interaction between the early T-lymphocyte activation 1 (Eta-1) protein and murine macrophages in vitro and its effect upon macrophages in vivo. J. Exp. Med., 171:1931-1942.

Somerman, M.J., Berry, J.E., Khalkhali-Ellis, Z., Osdoby, P., and Simpson, R.U. (1995) Enhanced expression of alpha v integrin subunit and osteopontin during differentiation of HL-60 cells along the monocytic pathway. Exp. Cell Res., 216:335-341.

Teitelbaum, S.L., Abu-Amer, Y., and Ross, F.P. (1995) Molecular mechanisms of bone resorption. J. Cell. Biochem., 59:1-10. 
Todd, R.F., III, Adams, M.D., Rogers, C.E., Tripp, L.R., and Liu, D.Y. (1988) Evidence for an intracellular pool of a migration inhibitory factor-associated, activation antigen of human mononuclear phagocytes, Mo3e. J. Immunol., 140:1095-1100.

Tsiftsoglou, A.S., and Robinson, S.H. (1992) Origins and properties of hematopoietic growth factor-dependent cell lines. In: Concise Reviews in Clinical and Experimental Hematology. M.J. Murphy Jr. ed. Alpha Med Press, Dayton, Ohio, pp. 270-294.

Weber, G.F., Asshkar, S., Glimcher, M.J., and Cantor, H. (1996) Re- ceptor-ligand interaction between CD44 and osteopontin (Eta-1). Science., 271:509-512

Xuan, J.W., Hota, C., and Chambers, A.F. (1994) Recombinant GSThuman osteopontin fusion protein is functional in RGD-dependent cell adhesion. J. Cell Biochem., 54:247-55.

Young, M.F, Kerr, J.M., Termine, J.D., Wewer, U.M., Wang, M.G., McBride, O.W., and Fisher, L.W. (1990) cDNA cloning, mRNA distribution and heterogenity, chromosomal location, and RFLP analysis of human osteopontin (OPN). Genomics, 7:491-502. 